\title{
The Effect of Foreign Language Competences and Student Mobilities on Graduates' Employability in the European Labour Market
}

\author{
Dagmar Kozelová - Helena Frančáková - \\ Irena Felixová - Miriam Pietriková
}

\begin{abstract}
Foreign language competences belong to the employers' essential requirements set for workforce. The enhancement of acquired competences and the acquisition of new ones form a part of higher education. In the paper employability of the graduates of the Faculty of Biotechnology and Food Sciences in the Slovak University of Agriculture in Nitra on the European labour market has been analysed. The graduates completed their study in the years 2007-2011. A questionnaire was used to survey 300 graduates by the 30th June 2011, out of which 103 responded. The Faculty of Biotechnology and Food Sciences prepares professionals in the fields of biotechnology, food technology, applied biology, hygiene and food safety. Input data have been evaluated by the methods of analysis, synthesis and comparison. In relation to the mathematical-statistical methods used, the input data have been classified according to the qualitative and statistical characteristics and evaluated by the association tables and graphs. We have come to the conclusion that foreign language competences are actively used by $43 \%$ of the respondents in different sectors of national economy, and the dominant foreign language is English. Within half a year after graduation 74\% of respondents who had taken part in student mobilities, and $48 \%$ of respondents who did not participate in them, found jobs on the labour market. The time of getting the first job is influenced not only by knowledge, working skills and other competencies but also by current job vacancies.
\end{abstract}

Key words: graduate, foreign language competences, student mobilities, labour market.

\section{Introduction}

International transfer of information and knowledge belongs to the essential needs in all spheres of life. In concordance with the words of L'. Török and L. Mura (2011) regionalization and globalization dramatically shifted the boundaries of mutual communication. Foreign language communication in today's multicultural world is a prerequisite of better success on the labour market. The whole learning process is focused on the acquirement and mastering of all language functions and competences, through which the students gain the ability to understand and express their thoughts, feelings, facts and opinions in both oral and written forms (reading, writing, listening and speaking) appropriately to the needs in specific real professional, social and cultural situations. In accordance with the "Key Competences for Lifelong Learning - a European Reference Framework" (2007), the Slovak University of Agriculture (SAU) also aims at the improvement of students' foreign language skills, which promote social cohesion and employability in a knowledge society. The students in all accredited programs at individual faculties of SAU are prepared to meet all requirements for being employed in the European labour market. The Faculty of Biotechnology and Food Sciences (FBFS) prepares academically educated professionals in the fields of biotechnology, food technology, applied biology, hygiene and food safety (see www.fbp.uniag.sk). The aim of this paper is to evaluate the data and information on the employability of FBFS graduates in the European labour market. The paper analyzes the graduates in various sectors of national economy, it evaluates the students' mobilities, the use of foreign language skills and the time of getting the first job.

\footnotetext{
* Dagmar Kozelová, Slovak University of Agriculture, Nitra, Slovakia; dagmar.kozelova@uniag.sk Helena Frančáková, Slovak University of Agriculture, Nitra, Slovakia; helena.francakova@uniag.sk Irena Felixová, Slovak University of Agriculture, Nitra, Slovakia; irena.felixova@ fem.uniag.sk Miriam Pietriková, Slovak University of Agriculture, Nitra, Slovakia; miriam.pietrikova@fem.uniag.sk
} 


\section{Acta Technologica Dubnicae \\ volume 2, 2012, issue 1}

\section{Methodology}

There are primary and secondary data used in the paper. The primary source of data was a questionnaire survey. The questionnaire focused on the employment of the graduates of the Faculty of Biotechnology and Food Sciences in various sectors of national economy. The survey was conducted in the period from the 1st March 2011 to the 30th June 2011. Secondary sources of the data were literary resources available from electronic databases of Slovak Agricultural Library at SAU and from other scientific resources, scientific journals and the like.

The questionnaires were sent to 300 randomly selected alumni from graduation years 2007 to 2011 from all regions of Slovakia. The amount of returned questionnaires achieved around $34 \%$. The studied group consisted of 103 graduates, 75 women and 28 men. The input data were evaluated by the methods of analysis, synthesis and comparison. In relation to the mathematical-statistical methods used, the input data were classified according to the qualitative and statistical characteristics and evaluated by the association tables and graphs.

\section{Results and Discussion}

Changing demands on workforce and technology in the global knowledge economy make the vocational training difficult. Much broader skills and competences than just the acquirement of scientific and technological knowledge are needed. The Reference Framework specifies eight key competences (URL 1):

- communication in the mother tongue;

- communication in foreign languages;

- mathematical competence and basic competences in science and technology;

- digital competence;

- learning to learn;

- social and civic competences;

- initiative and entrepreneurship;

- cultural awareness and expression.

In our opinion, some key requirements are imposed on the personality of managers, people with higher education, such as innate characteristics, natural intelligence and acquired managerial characteristics. These include expertise and experience (also foreign), economic knowledge, socio-psychological knowledge and knowledge of management methods. For being a good manager, the managerial skills such as technical, technological skills, conceptual skills and social (communication) skills are also important. According to R. Dušek (2011) the graduates do not need only to gain the knowledge and skills but also to keep, develop and successfully use them in practice.

We examined the views of respondents who graduated between 2007 and 2010. The examined group of respondents consists of 19 graduates (18\%) of graduation year 2007, 33 graduates (32\%) of 2008, 23 graduates (22\%) of 2009 and 28 graduates (27\%) of 2010. The respondents have completed the university education in the following study programs: biotechnology $-24.2 \%$, food technology -67.9 $\%$ and applied biology $-7.8 \%$ of respondents. The data on the graduates' employability are by $\mathrm{Z}$. Freibergová (1997) a valuable basis for school management at assessing the quality of educational process, they are an important source of information used in professional consultancy and they can also be used in a comparative study of successful graduates of individual schools on the labour market or as a part of a school marketing study. At present, schools must create adequate conditions for the formation of a universal future professional equipped by good foreign language competences. These measures endeavour to minimize the risk of graduate unemployment. These issues are dealt with, among others, also by L. Mura (2010). Young people, university graduates, who cannot enter the labour market, are exposed to psychological problems and depression (Heretik et al., 2011). 


\section{Acta Technologica Dubnicae \\ volume 2, 2012, issue 1}

\subsection{Activities of the respondents on the labour market}

According to D. Lamberton (2002) it is necessary to prepare the workforce in such a way that they are able to operate effectively in individual job positions, and also to increase the competitiveness of entrepreneurial entities and thus the competitiveness of the industry. The analysis of the graduates' activities in various sectors showed that out of the overall number of respondents $12.6 \%$ of them work in agriculture, $21.3 \%$ in food production and $25 \%$ of respondents are employed in educational institutions for agro-food industry. The respondents work at different positions involved in the economic performance of the whole.

Figure 1 The proportion of respondents employed in various sectors of national economy broken down by SK NACE

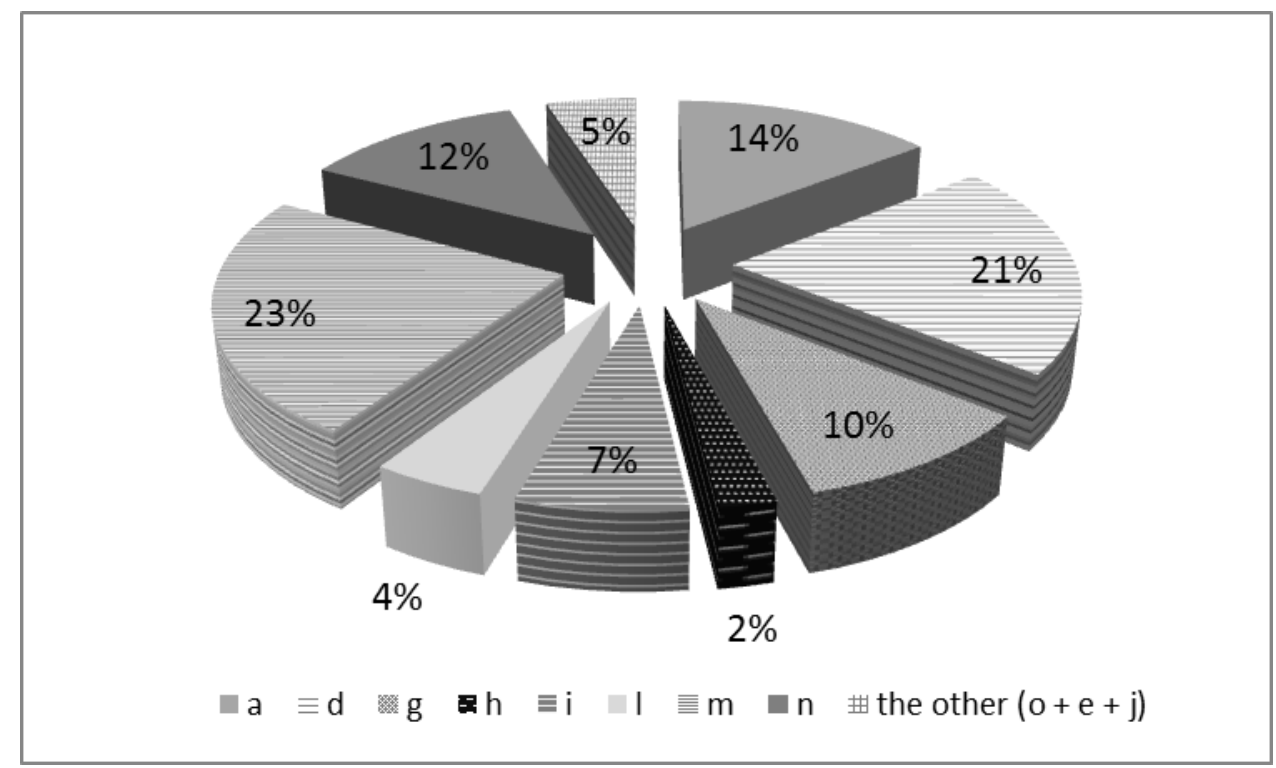

Figure 2 Number of respondents in the national economy according to the completed study program broken down by SK NACE

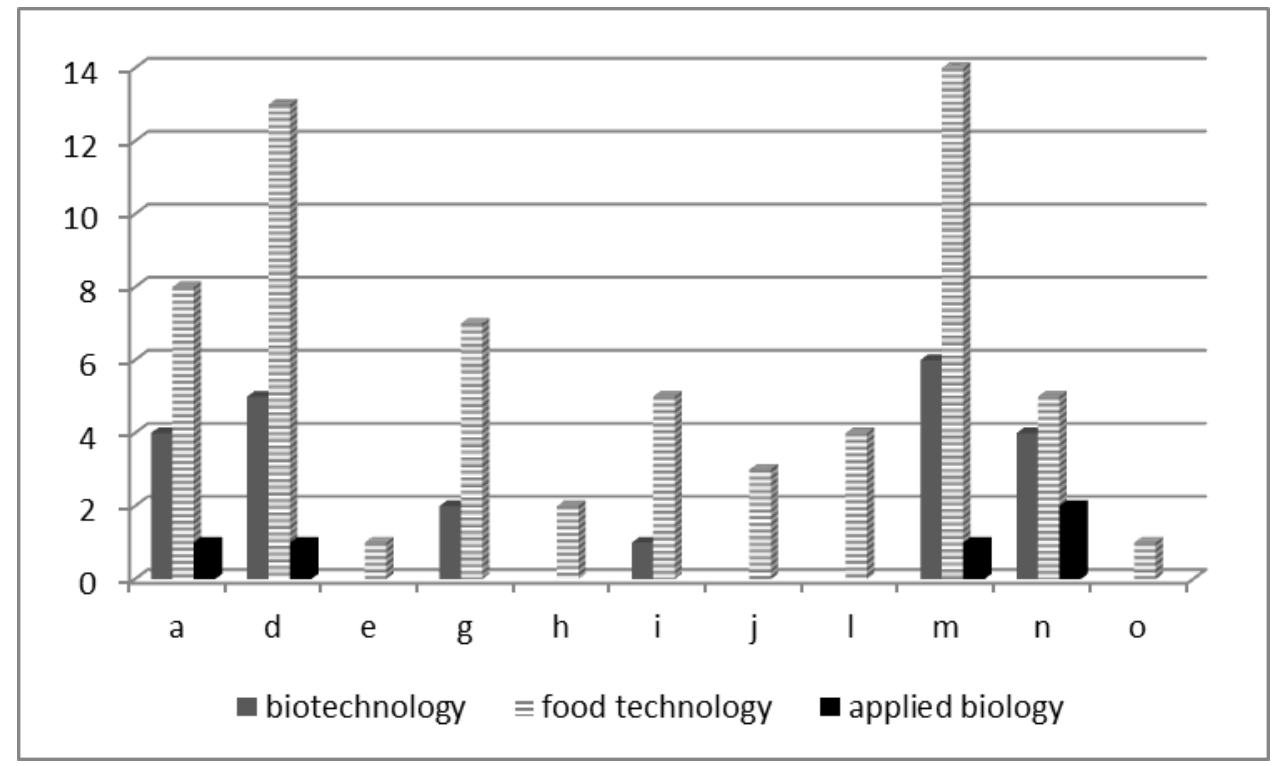

A - agriculture, D - manufacturing, $\mathrm{G}$ - wholesale and retail trade, $\mathrm{H}$ - hotels and restaurants, $\mathrm{I}$ - transport, storage, $\mathrm{L}$ - public administration, $\mathrm{M}$ - education, $\mathrm{N}$ - health care, $\mathrm{O}$ - other community and social services, $\mathrm{E}-$ electricity production and distribution, $\mathrm{J}$ - financial intermediation 


\section{Acta Technologica Dubnicae \\ volume 2, 2012, issue 1}

Out of all respondents $10.7 \%$ operate in the sphere of health and social care, $8.7 \%$ of them in the wholesale and retail trade, $5.8 \%$ of the respondents work in the sectors of transport and storage, $3.9 \%$ in public administration, defence and welfare, and $2.9 \%$ of respondents work in financial intermediation. In the manufacture and distribution of electricity, gas and water work $0.9 \%$ of the respondents and other community, social and personal services are provided by $0.9 \%$ of the respondents. Figure 2 documents the fact that $88 \%$ of the graduates are active in the field of their study. To the deadline for submission of questionnaires there were $10.7 \%$ of the respondents unemployed. On the Slovak labour market there were $82 \%$ of the respondents employed and $10 \%$ of them worked abroad (the Republic of Ireland, the Czech Republic, Switzerland, the United Kingdom and Slovenia).

\subsection{Student mobilities}

A key requirement in achieving a "global responsibility", according to G. L. Downey et al. (2006), is the art to work effectively with people who define problems in a different way than the others. D. E. Chubin et al. (2005) claim that such an outcome can be achieved by students being exposed to the solution of problems in a multicultural environment. The European Credit Transfer System (ECTS) adopted at the Slovak University of Agriculture enables the students to complete internships and study stays at universities, in companies, businesses, or on farms abroad. The primary precondition in the expansion of student mobilities within the European higher education area is by E. Rohálová (2005) the enhancement of foreign language communicative competences of the students.

We found out that the stay abroad was completed by $18.4 \%$ of respondents, out of which $3.9 \%$ completed the study stay (student mobility), $0.9 \%$ completed the study stay and at the same time they had the possibility to work and $13.6 \%$ of respondents worked abroad.

\begin{tabular}{|l|l|l|l|l|l|}
\hline Student mobility & 2007 & 2008 & 2009 & 2010 & altogether \\
\hline Participated & 9 & 2 & 6 & 2 & 19 \\
\hline Did not participate & 10 & 31 & 17 & 26 & 84 \\
\hline altogether & 19 & 33 & 23 & 28 & 103 \\
\hline
\end{tabular}

Table 1 Overview of the respondents' student mobilities

\subsection{Foreign Language Competences}

Teaching foreign language skills and competencies at the Department of Professional Language Education of the Faculty of Economics and Management at SAU is based primarily on the specific needs of the students and the teachers try to simulate specific life situations in which students can occur and work. That is the reason why such methods as model situations, case studies, training, project writing and presenting play an irreplaceable role in foreign language lessons. All of the mentioned methods require team work, and thus simulate the social environment in which students will work after graduating from the university.

Model situations and, in particular, case studies help students acquire not only language skills and confidence which they can apply as future employees of multinational organizations, but also intercultural knowledge and understanding. Therefore the main goal of language education is to learn vocabulary, phraseological units, professional style in simulations of authentic situations, such as: conducting meetings, interviews, business meetings and negotiations or business correspondence. In the period of market globalization and society focused on knowledge economy the foreign language competences of individuals play an important role. In the questionnaire, participants were also asked if they used foreign languages after graduating from the SAU.

We found out that $39.8 \%$ of respondents were trying to improve their foreign language competence after completing the second degree of higher education at FBFS in organized forms through language courses and $13.6 \%$ of them within the doctoral study in order to achieve the $\mathrm{PhD}$ degree. There are $41.7 \%$ of respondents who enhance their foreign language skills through a self-study. Communication 


\section{Acta Technologica Dubnicae \\ volume 2, 2012, issue 1}

skills in foreign languages are applied by $43.7 \%$ of respondents, $2.9 \%$ of them communicate actively in two world languages (English + German, English + Spanish) and 25.2\% of respondents communicate in their mother tongue and English and 6.8\% of them in German language.

Figure 3 Overview of the respondents' use of foreign language competences

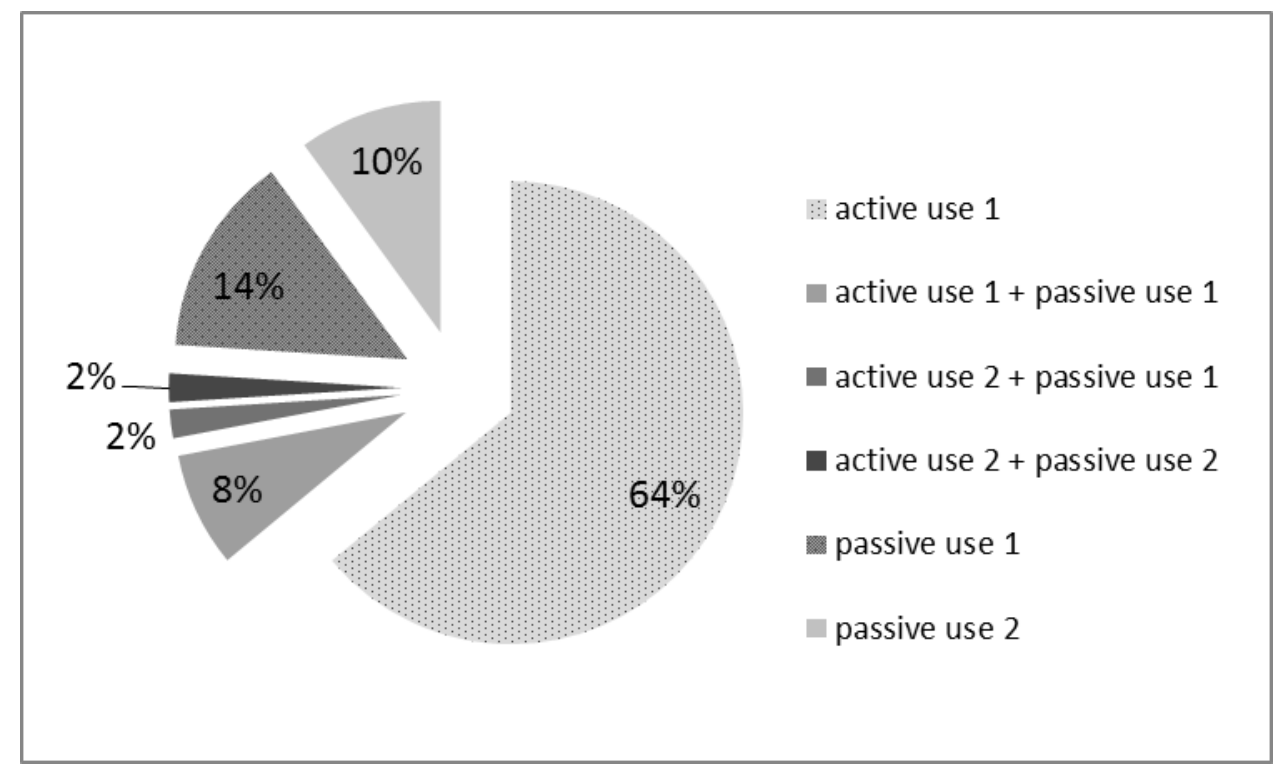

There are $8.7 \%$ of the respondents who communicate in two foreign languages, one actively (mainly English), and the other passively. Out of all respondents $4.8 \%$ have passive knowledge of two languages (English + German, German + Russian), 8.7\% of the respondents speak only English, 4.8\% of the respondents can speak German, and French is used by $0.9 \%$ of the respondents. The remaining $46.6 \%$ of the respondents have not used their foreign language communication skills yet. We assumed that the respondents who completed their mobility stays abroad have better chance to get job on labour market than those respondents who have not completed the mobility. This hypothesis was confirmed. Within half a year after graduation $74 \%$ of the respondents who took part in mobility could find a job while out of those who did not participate in any mobility just $48 \%$ of respondents were employed.

Figure 4 Time needed for getting the first job depicted in relation to student mobilities

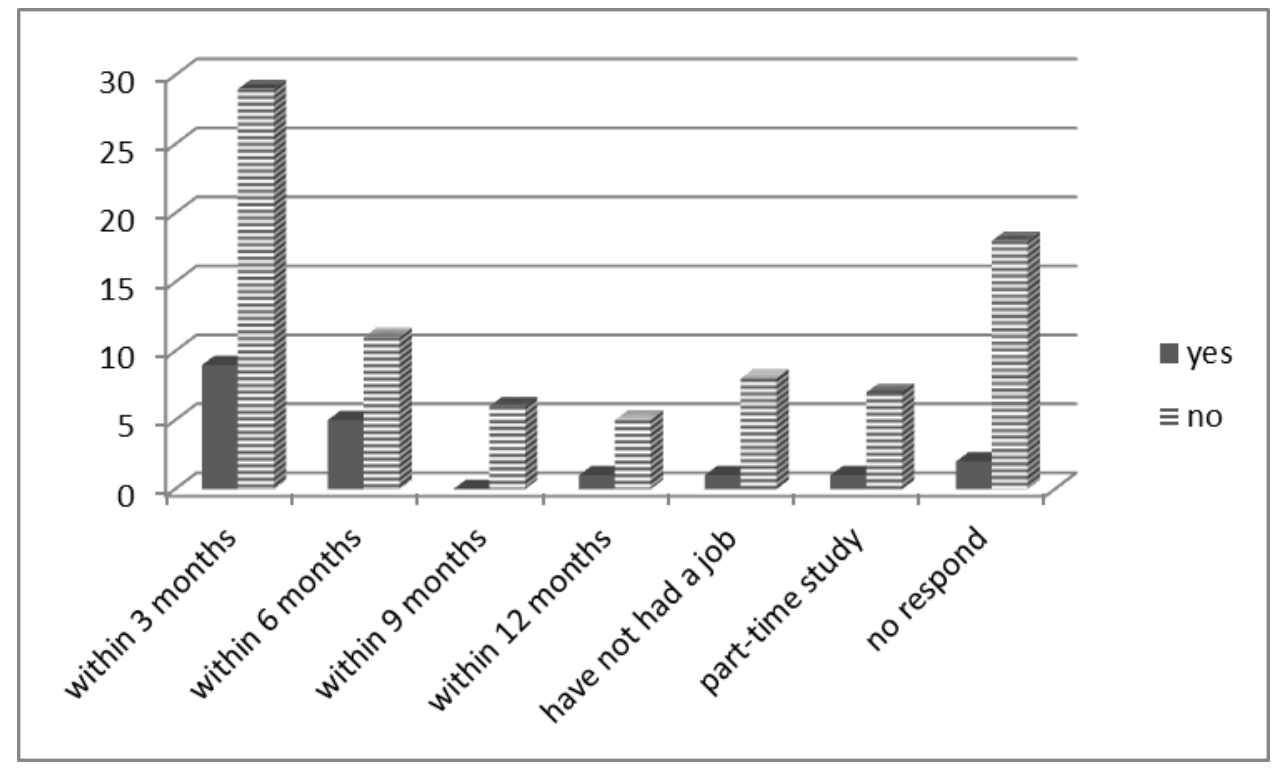




\section{Acta Technologica Dubnicae \\ volume 2, 2012, issue 1}

By examining the time needed for getting the first job, we found out that $68 \%$ of the respondents of graduation year 2007, 79\% of the respondents of 2008, 77\% of 2009 and just $42 \%$ of the respondents of 2010 started their job within half a year. Comparison of these data confirms the fact that some respondents of graduation year 2010 had bigger problems to get suitable vacancy on the labour market than the respondents from previous years. The realised analysis showed that the graduates who completed mobility abroad during their studies could find job much earlier than the graduates who did not use such opportunities. It must be noted that to find a suitable job in the field of study also depends on vacancies in the labor market in a given region of Slovakia and also in international labor markets. The ongoing economic and financial crisis is also reflected in Slovakia, where the rate of unemployment in various regions differs significantly. We expect that the graduates of FBFS will use their expertise, language, and laboratory (practical) skills in the labor market more intensively. This intensive use of the knowledge and skills can be expected after more favorable macroeconomic and stable microeconomic conditions will be created.

\section{Conclusions}

The participation in the student mobilities abroad increases students' level of expertise and foreign language communication skills and creates better conditions for their employability on the European labour market. It enables the graduates as future managers to fulfill business objectives more effectively and to cope successfully with difficult situations at work. We found out that within half a year $74 \%$ of the respondents participating in mobility and $48 \%$ of the respondents who did not participate in any mobility could find a job on the labour market. The time of getting the first job is influenced to a large extent by the existing job vacancies on the labour market.

\section{References}

DOWNEY, G. L. et al.: The globally competent engineer: Working effectively with people who define problems differently. In: Journal of Engineering Education, vol. 95, 2006, no. 2, p. 103.120.

DUŠEK, R.: Uplatnení absolventu Zemedelské fakulty Jihočeské univerzity na trhu práce. [Achievement in labour market of the graduates of Faculty of Agriculture of the University of South Bohemia.] In: Acta Universitatis Bohemiae Meridionales, vol.12, 2011, no.2, p.45

FREIBERGOVÁ, Z.: Význam informací o uplatnení absolventu vysokých škol na trhu práce. In: Rozvoj profesního poradenství na českých univerzitách. Praha: ČZU, 1997, p. 19-28.

HERETIK, A. - MURA, L. - BETÁKOVÁ, J.: Statistical Research of the Unemployment Depression Relation (part 1). [Štatistické skúmanie vzt'ahu nezamestnanost' - depresia (prvá čast')]. In: Forum Statisticum Slovacum, vol. 7, 2011, no. 5, p. 41-46.

CHUBIN, D. E. - MAY, E. - BABCO, E. L.: Diversifying the engineering workforce. In: Journal of Engineering Education, vol. 94, 2005, no. 1, p. 73-86.

LAMBERTON, D.: Managing the global: Globalization, employment and quality of life. London (GreatBritain) - New York (USA): I. B. Tauris CoLtd Publishing, 2002, 268 p.

MURA, L.: Statistics of Employability in Self-governing Regions in Selected Sectors of Economy in Slovakia. [Štatistika zamestnanosti v samosprávnych krajoch vo vybraných odvetviach hospodárstva Slovenska.] In: Forum Statisticum Slovacum, vol. 6, 2010, no. 4, p. 130-135.

ROHALOVÁ, E.: Basic determinants of adaptation of Slovak university of agriculture in Nitra graduates on European labour market. [Základné determinanty adaptácie absolventov SPU na potreby európskeho trhu práce.] In: Uplatnenie absolventov vysokých škôl na trhu práce v podmienkach Európskej únie. Zborník vedeckých prác z medzinárodnej konferencie. Nitra: Jamiss, 2005, p. 14.

TÖRÖK, L. - MURA, L.: Statistical survey of translation processes preferences. [Štatistické zist'ovanie preferencií prekladatel'ských postupov.] In: Forum Statisticum Slovacum, vol. 7, 2011, no. 7, p. 257-263.

URL 1. Key competences for lifelong learning. European Reference Framework. Kl'účové kompetencie pre celoživotné vzdelávanie. Európsky referenčný rámec. 2007. [Cit. 2011-12-15] Available at: http://ec.europa.eu/dgs/education_culture/publ/pdf/ll-learning/keycomp_sk.pdf 